\title{
Obstructive jaundice due to ampullary metastasis of renal cell carcinoma
}

\author{
Andreas Karakatsanis ${ }^{1 *}$, Antonios Vezakis ${ }^{1}$, Georgios Fragulidis $^{1}$, Chryssa Staikou², Eleni E Carvounis ${ }^{3}$ \\ and Andreas Polydorou ${ }^{1}$
}

\begin{abstract}
Renal cell carcinoma is often characterized by the presence of metachronous metastases in unusual sites. The presence of isolated metastases is treated with surgical excision with good anticipated results. On the other hand, systemic chemotherapy is administered in the context of metastatic spread, usually sunitib or sorafenib. In such cases, however, the presence of symptomatic foci calls for minimal intervention.

We present a case of a 77-year-old patient who presented with obstructive jaundice due to an ampullary mass. Endoscopic excision and biopsy set the diagnosis of metastatic renal cell carcinoma. Consequently, imaging studies revealed the presence of multiple foci in the lungs and bone. Therefore, pancreatoduodenectomy was excluded and the patient underwent endoscopic ampullectomy and was set to oral sunitinib. Interestingly, despite generalized spread, local control was achieved until the patient succumbed to carcinomatosis.

Painless obstructive jaundice in a patient with history of renal cancer and negative computed tomography scanning for pancreatic or other causes of obstruction should alert for prompt investigation for an ampullary metastasis.
\end{abstract}

\section{Background}

Obstructive jaundice is one of the most typical clinical signs caused by inflammation, gallstones or tumors of the periampullary region. Painless and progressive rise of serum bilirubin, however, is mostly attributed to tumorigenic entities, rather than inflammatory processes.

\section{Case presentation}

A 77-year-old male presented with painless obstructive jaundice. He had a history of right nephrectomy for a $\mathrm{T}_{2} \mathrm{~N}_{0} \mathrm{M}_{0}$ renal clear cell carcinoma 3 years ago. Ultrasound and abdominal computed tomography (CT) scanning depicted the common bile duct dilated up to its distal end. Endoscopic retrograde cholangiopancreatography (ERCP) revealed an ampullary tumor (Figure 1). Consequently, ampullectomy with endoscopic sphincterotomy and placement of a plastic $10 \mathrm{Fr}$ biliary stent were performed (Figure 2A).

Histology showed a clear cell carcinoma, consistent with renal origin. Immunochemistry confirmed the diagnosis [vimentin(+), CD10(+), CK8(+), RCCa antigen(+)]. Further

\footnotetext{
* Correspondence: andreas.karakatsanis@gmail.com

²nd Department of Surgery, Aretaieion Hospital, Medical School, National and Kapodistrian, University of Athens, Athens, Greece

Full list of author information is available at the end of the article
}

evaluation with chest $\mathrm{CT}$ and radionuclide bone scanning revealed the presence of lung and bone metastases. The presence of multiple metastatic foci excluded the need for pancreatoduodenectomy and the patient was treated with oral sunitinib. For better palliation, repeat ERCP was performed a month later and additional excision of remnant tissue was performed in combination with argon plasma coagulation (APC) and placement of a partially covered metallic biliary stent (Wallstent; Boston Scientific, Natick, MA) (Figure 2B). Six months later the stent was removed and multiple biopsies showed no evidence of residual tumor (Figure 3). The patient was re-evaluated with endoscopy every 6 months. The patient succumbed to metastatic disease 1.5 years later without jaundice or abnormal liver function tests.

\section{Conclusion}

Renal cancer counts approximately for $3.8 \%$ of all adult malignancies [1]. The treatment for localized disease is radical nephrectomy, despite the fact that recent data suggest that less extended procedures in selected patients, such as nephron-sparing surgery (partial nephrectomy) as well as laparoscopic procedures, hold the same results in terms of survival rate [2-6]. Surgical excision is considered

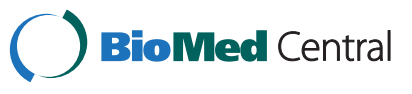




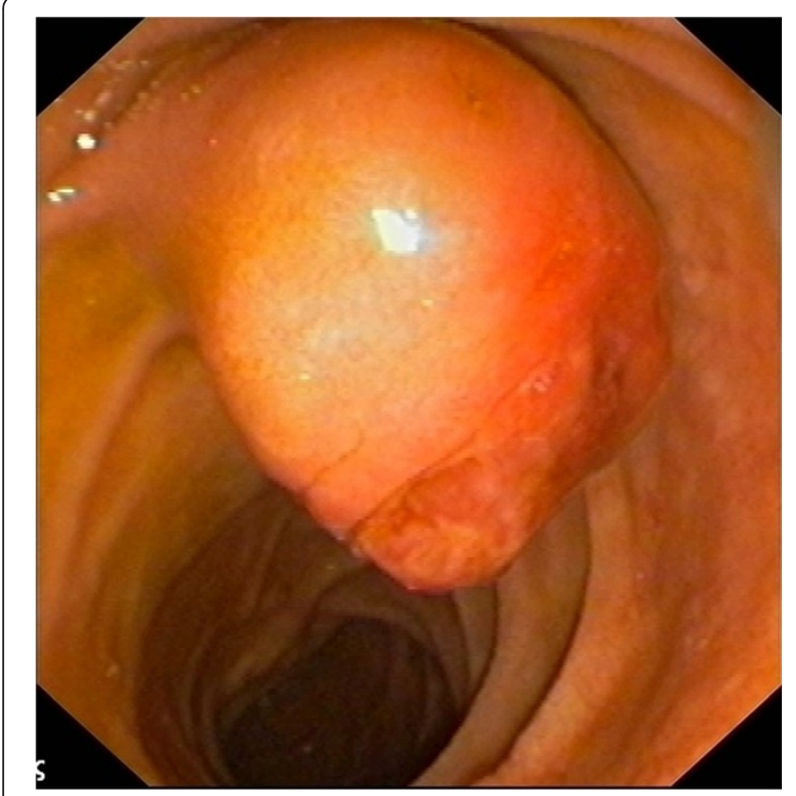

Figure 1 The ampullary mass depicted in endoscopy.

curative in 71 to $97 \%$ of patients with localized disease (pathologic stage pT1-2), whereas 5-year cancer-specific survival rates after nephrectomy decrease to 20 to $53 \%$ for patients with locally advanced tumors and below $15 \%$ for patients with metastatic disease [7]. Respectively, the rate of recurrence, even in cases of resection with curative intent, is high, ranging from 20 to $30 \%$. It is estimated that, in total, $50 \%$ of the patients with renal carcinoma will present with or eventually develop metastatic disease [8]. Adjuvant therapy consisting of IL-2 and IFN-a, which was

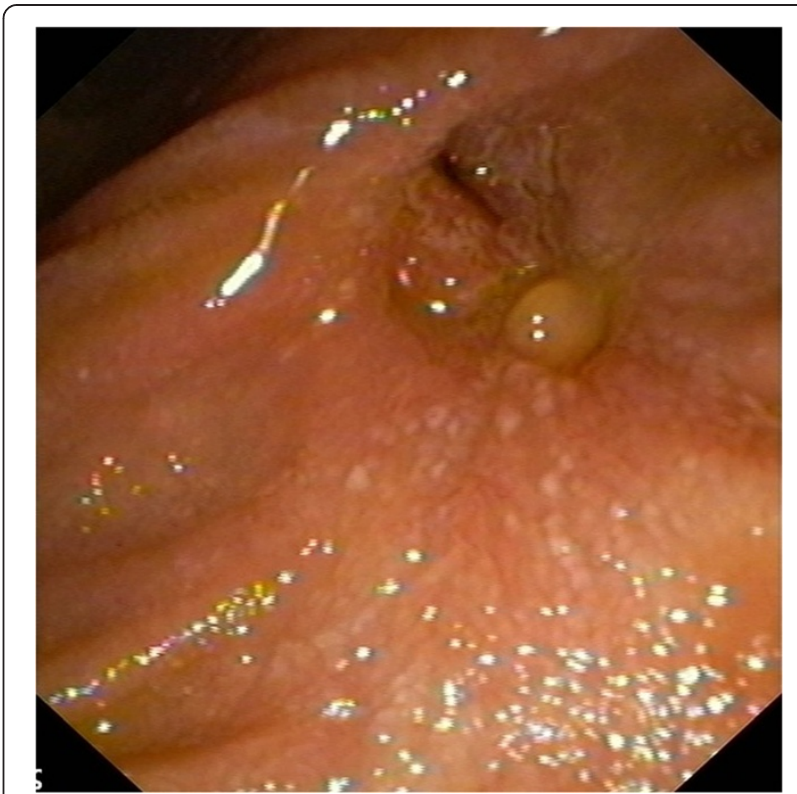

Figure 3 Endoscopic image of the papilla 6 months after treatment, depicting good local control of the lesion.

considered the standard of care for many years, held very low response rates. Recent advances in our understanding of the biology of renal cell carcinoma led to the development of novel targeted therapies such as mTOR (mammalian target of rapamycin) inhibitors as temsirolimus or the inhibitors of the split-kinase-domain family of receptors of tyrosine kinase sunitinib and sorafenib, which prevent tumor angiogenesis through vascular endothelial growth factor inhibition (mTOR and VEGF are commonly

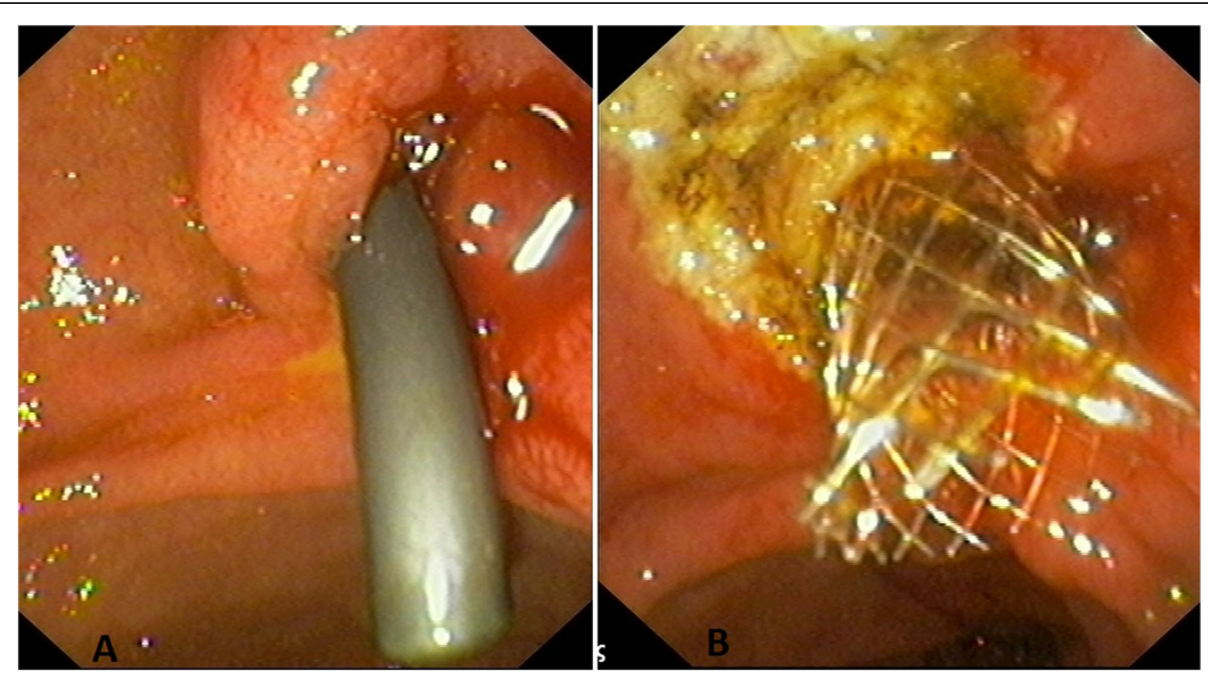

Figure 2 (A) Image of the ampulla after ampullectomy, endoscopic sphincterotomy and the placement of a plastic $10 \mathrm{Fr}$ biliary stent. Post ampullectomy endoscopy (B) The papilla after additional excision of remnant tissue in combination with argon plasma coagulation and placement of a partially covered metallic biliary stent, 1 month after the initial intervention. One month later, additional argon plasma coagulation and metallic stent placement. 
used and may be explained but not substituted). Response rates are currently under investigation in trials; sunitinib, however, has been established as first-line treatment for advanced renal cell carcinoma (RCC) [9]. Usual sites of metastatic spread are the liver, the lungs, the brain and the bones, whereas less common sites are the gallbladder and the urinary bladder. Metastases usually occur in the first 3 years after nephrectomy. However, metastatic foci from renal cancer have been reported as late as 25 years after radical nephrectomy which was considered curative [10].

Ampullary metastases from RCC are quite rare. Sporadic reports of isolated metastases in the ampulla of Vater involved lesions which presented with obstructive jaundice [11], malabsorption [12] or obscure gastrointestinal bleeding, with the prevailing mode of spread being the hematogenous route [13]. Diagnosis is usually set by endoscopic biopsy, since cross-sectional imaging may often fail to delineate a lesion. The treatment proposed for isolated lesions is pancreatoduodenectomy, since data demonstrate sufficient median survival (26 months) and an actuarial 5 -year survival of $75 \%$. It is important to denote that, out of the tumors that metastasize in the pancreas and the periampullary region, renal cancer yields the most favorable prognosis; therefore surgical excision is advocated in cases of isolated foci [14-16]. However, this operative approach is not indicated in the presence of multiple metastatic foci and such patients are treated with systematic chemotherapy. The therapeutic challenge is the presence of subsequent complications due to the presence of an ampullary lesion such as in our case, in which intervention was mandatory for the relief of obstructive jaundice. The efficacy of endoscopic resection for benign lesions of the ampulla has been proven $[17,18]$ and has been advocated for small tumors in high-risk patients as a low-risk, minimally invasive procedure [19]. Tumor-free margin can be obtained despite the fact that there had been past reports of local recurrence up to $26 \%$ when endoscopic snare excision was utilized [20], since techniques such as APC mitigate such concerns [21]. It is clear that limitations to the efficacy of the method, such as the size of the lesion (larger than $50 \mathrm{~mm}$ ) and the imaging features in the endoscopic ultrasound or intraductal ultrasound [22], do not apply strictly when the procedure is palliative, such as in our case. It is evident that the ideal result would be ampullectomy with clear resection margins, but the aid of fulgurating techniques such as APC may provide equal results. In our patient, local control was achieved until he succumbed. It seems that in the hands of an experienced endoscopist, endoscopic ampullectomy is a safe and effective procedure in order to provide palliation from metastatic foci in patients with disseminated disease, as well as in high-risk patients who are not candidates for pancreatoduodenectomy.
Keypoints for successful outcome are negative resection margins and endoscopic surveillance [23], but primarily clinical suspicion that the presence of painless jaundice in a patient with history of renal cancer and negative CT scanning for pancreatic or other causes of obstruction should alert for prompt investigation for an ampullary metastasis.

\section{Consent}

Written informed consent was obtained from the next of kin of the patient for publication of this Case report and any accompanying images. A copy of the written consent is available for review by the Editor-in-Chief of this journal.

\section{Abbreviations}

APC: Argon plasma coagulation; CT: Computed tomography;

ERCP: Endoscopic retrograde cholangiopancreatography; IFN: Interferon; IL: Interleukin; RCC: Renal cell carcinoma.

\section{Competing interests}

The authors declare that they have no competing interests.

\section{Author's contributions}

AV and AP performed endoscopy and reviewed the images. EK collected the data. AK, CS and GPF reviewed literature,drafted and wrote the manuscript. All authors read and approved the final manuscript.

\section{Author details}

'2nd Department of Surgery, Aretaieion Hospital, Medical School, National and Kapodistrian, University of Athens, Athens, Greece. ${ }^{2} 1$ st Department of Anesthesiology, Aretaieion Hospital, Medical School, National and Kapodistrian, University of Athens, Athens, Greece. ${ }^{3}$ Department of Pathology, Aretaieion Hospital, Medical School, National and Kapodistrian, University of Athens, Athens, Greece.

Received: 7 February 2013 Accepted: 19 September 2013

Published: 7 October 2013

\section{References}

1. Jemal A, Siegel R, Xu J, Ward E: Cancer statistics. CA Cancer J Clin 2010, 60:277-300.

2. Clayman RV, Kavoussi LR, Soper NJ, Dierks SM, Meretyk S, Darcy MD, Roemer FD, Pingleton ED, Thomson PG, Long SR: Laparoscopic nephrectomy: initial case report. J Urol 1991, 146:278-282.

3. Portis AJ, Yan Y, Landman J, Chen C, Barrett PH, Fentie DD, Ono Y, McDougall EM, Clayman RV: Long-term follow up after laparoscopic radical nephrectomy. J Urol 2002, 167:1257-1262.

4. Lau WK, Blute ML, Weaver AL, Torres VE, Zincke H: Matched comparison of radical nephrectomy vs nephron-sparing surgery in patients with unilateral renal cell carcinoma and a normal contralateral kidney. Mayo Clin Proc 2000, 75:1236-1242.

5. Uzzo RG, Novick AC: Nephron sparing surgery for renal tumors: indications, techniques and outcomes. J Urol 2001, 166:6-18.

6. Hafez KS, Novick AC, Campbell SC: Patterns of tumor recurrence and guidelines for follow up after nephron sparing surgery for sporadic renal cell carcinoma. J Urol 1997, 157:2067-2070.

7. Zisman A, Pantuck AJ, Dorey F, Chao DH, Gitlitz BJ, Moldawer N, Lazarovici $D$, de Kernion JB, Figlin RA, Belldegrun AS: Mathematical model to predict individual survival for patients with renal cell carcinoma. J Clin Oncol 2002, 20:1368-1374.

8. Janzen NK, Kim HL, Figlin RA, Belldegrun AS: Surveillance after radical or partial nephrectomy for localized renal cell carcinoma and management of recurrent disease. Urol Clin North Am 2003, 30(4):843-852.

9. Najjar YG, Rini BI: Novel agents in renal carcinoma: a reality check. Ther Adv Med Oncol 2012, 4(4):183-194.

10. Shiono S, Yoshida J, Nishimura M, Nitadori J, Ishii G, Nishiwaki Y, Nagai K Late pulmonary metastasis of renal cell carcinoma resected 25 years after nephrectomy. Jpn J Clin Oncol 2004, 34:46-49. 
11. Bolkier M, Ginesin Y, Moskovitz B, Munichor M, Levin DR: Obstructive jaundice caused by metastatic renal cell carcinoma. Eur Urol 1991, 19(1):87-88.

12. McKenna Jl, Kozarek RA: Metastatic hypernephroma to the ampulla of Vater: an unusual cause of malabsorption diagnosed at endoscopic sphincterotomy. Am J Gastroenterol 1989, 84:81-83.

13. Janzen RM, Ramj AS, Flint JD, Scudamore CH, Yoshida EM: Obscure gastrointestinal bleeding from an ampullary tumour in a patient with a remote history of renal cell carcinoma: a diagnostic conundrum. Can J Gastroenterol 1998, 12:75-78.

14. Le Borgne J, Partensky C, Glemain P, Dupas B, de Kerviller B: Pancreaticoduodenectomy for metastatic ampullary and pancreatic tumors. Hepatogastroenterology 2000, 47:540-544.

15. Sohn TA, Yeo CJ, Cameron JL, Nakeeb A, Lillemoe KD: Renal cell carcinoma metastatic to the pancreas: results of surgical management. J Gastrointest Surg 2001, 5:346-351.

16. Machado NO, Chopra P: Pancreatic metastasis from renal cell carcinoma managed by Whipple's resection. A case report and literature review of metastatic pattern, surgical management and outcome. JOP 2009, 6(10):413-418.

17. Katsinelos P, Paroutoglou G, Kountouras J, Beltsis A, Papaziogas B, Mimidis K, Zavos C, Dimiropoulos S: Safety and long-term follow-up of endoscopic snare excision of ampullary adenomas. Surg Endosc 2006, 20:608-613.

18. Catalano MF, Linder JD, Chak A, Sivak MV Jr, Raijman I, Geenen JE, Howell DA: Endoscopic management of adenoma of the major duodenal papilla. Gastrointest Endosc 2004, 59:225-232.

19. Hoyuela C, Cugat E, Veloso E, Marco C: Treatment options for villous adenoma of the ampulla of Vater. HPB Surg 2000, 11:325-330. discussion 330-331.

20. Shemesh E, Nass S, Czerniak A: Endoscopic sphincterotomy and endoscopic fulguration in the management of adenoma of the papilla of Vater. Surg Gynecol Obstet 1989, 169:445-448.

21. Patel R, Varadarajulu S, Wilcox CM: Endoscopic ampullectomy: techniques and outcomes. J Clin Gastroenterol 2012, 46:8-15.

22. Boix J, Lorenzo-Zúñiga V, Moreno dW, Domènech E, Gassull MA: Endoscopic resection of ampullary tumors: 12-year review of 21 cases. Surg Endosc 2009, 23:45-49.

23. Bellizzi AM, Kahaleh M, Stelow EB: The assessment of specimens procured by endoscopic ampullectomy. Am J Clin Pathol 2009, 132:506-513.

doi:10.1186/1477-7819-11-262

Cite this article as: Karakatsanis et al: Obstructive jaundice due to ampullary metastasis of renal cell carcinoma. World Journal of Surgical Oncology 2013 11:262.

\section{Submit your next manuscript to BioMed Central and take full advantage of:}

- Convenient online submission

- Thorough peer review

- No space constraints or color figure charges

- Immediate publication on acceptance

- Inclusion in PubMed, CAS, Scopus and Google Scholar

- Research which is freely available for redistribution 